\title{
EXPLORING PARENTS' HOME-BASED INVOLVEMENT IN THEIR CHILDREN'S ENGLISH LEARNING: TRIGGERS AND BARRIERS
}

\author{
Cicilia Siwi Triutami $^{1}$, Retno Muljani ${ }^{2}$ \\ Sanata Dharma University, Yogyakarta \\ ${ }^{1}$ siwicicilia@gmail.com, ${ }^{2}$ retnomuljani@usd.ac.id
}

\begin{abstract}
In Indonesian context, English has been taught in elementary school level and parents' involvement is considered as one of the influencing factors which has contribution to the children's language learning achievement. The rapid, complex and continuous societal changes in this digital era might impact and alter the possibilities of parents' involvement in their children's language learning. The current study explored the triggers and the barriers of parents' home-based involvement in their children's English language learning and the features of their involvement. The qualitative research by implementing semistructured, in- depth interview with four parents of elementary students at one of private schools in Yogyakarta city was conducted. The findings show the three main triggers in parents' home-based involvement namely: (1) parents' belief of the importance of English, (2) the implementation of school technological learning tools and (3) parents' expectation of their children academic achievement. While the barriers that parents encounter in their involvement are: (1) parents' lack of time, (2) parents' unproficiency in English and (3) parents' unfamiliarity with the use of technological tools. As the features of involvement, the study reveals parents' monitoring, accompaniment, assistances in their children's home-learning activities, providing some additional English learning media and financing English private course.
\end{abstract}

Keywords: Barriers, Children's English Language Learning, Parents' Home-Based Involvement, Triggers

\section{INTRODUCTION}

Since English has been globally used, it has significant roles in many human's domains, such as education, culture, politics, industry and ICT. Moreover, many countries have begun to introduce English teaching as a foreign language at an earlier level in the curriculum (Butler, 2014). In the Indonesian context, English as a foreign language has been taught at the primary school level due to the revision of 1994 curriculum. Accordingly, Indonesian students can start to learn English at their young age, elementary school level, in which there are some factors that affect the success of the language learning achievement. Parents' involvement has become one of the influencing factors for young children in language learning as it can provide motivation and encouragement during the processes (Hosseinpour, 2015; Rahman, 2015). Nevertheless, the rapid, complex and continuous societal changes in this digital era might impact and alter the possibilities of the triggers, barriers and features in parents' involvement.

Parents' involvement can be defined as the dedication of the parents' resources to their children. It is a multidimensional structure which consists of parents's educational desires, parents' decisions and plans for their children, and indeed, their engagement in children's school tasks (Ule, Živoder, \& Bois-reymond, 2015). Parents' participation in their children's education processes can be categorized into school-based and home-based involvement (Jeynes, 2007 as 
cited in Dewi et al., 2017). Parents' home-based involvement covers providing the supportive environment, stimulating children's $\mathrm{s}$ intellectual stimulation, supervising homework completion and parent-children discussion (Benner et al., 2016). Meanwhile, parents' schoolbased involvement includes the activities that parents undertake regarding to their participation in school organizations and also in other school events (Benner et al., 2016). Furthermore, Poyraz, (2017); Jafarov, (2015) and Larocque et al., (2011) assert that some aspects such as socio-economic situation and parents' educational experience can affect parents' involvement in their children language learning. Additionally, children's age contributes great influence on parents' activeness in their children's English language learning since it will decrease as children grade levels increase (Hornby \& Lafaele, 2011; Poyraz, 2017)

School's learning platform technologies are considered to increase parental involvement since these tools provide parents an access to gain information and resources related to their children's education as well as to support and review their children learning (Selwyn et al., 2011; Willis \& Exley, 2018). Research has shown that children's outcomes including behaviour, attendance, well being and academic achievement improve when parents highly get involved in their learning processes (Povey et al., 2016; Wilder, 2014) Moreover, the learning platform technologies are utilized to ensure the learning continuity by replicating the learning environment at home due to extreme learning conditions such as school closure. (Selwyn et al., 2011). However, the inability of parents to access the technological tools can be one of the obstacles (Goodall, 2017) and some parents regard learning platform merely just as an additional burden for them (Poyraz, 2017). Additionally, (Jafarov, 2015) states that parents lack of time can be one of problems in parental involvement.

Parents' involvement might also been triggered by their perception and belief of the importance of the language learning (Dewi et al., 2017; Mosty \& Lefever, 2013). Several researches reveal that English is perceived by most parents as a crucial language which their children need to acquire and it becomes more essential than for the parents themselves (Xiaoyi, 2017). Similarly, Wei (2011) discovers that both bilingual education and non-bilingual education parents view English as the important feature for their children future life. This perspective supports Fiszbein \& Stanton (2018) who consider learning at early childhood as a necessary investment. In addition, parents believe that learning foreign language can increase their children's self-image and confidence (Lin, Ching-Ying \& Chen, 2016). Mastering English will also support children in learning more knowledge as well as accessing a lot of information (Reddy \& English, 2016). Further, it will help them to achieve more understanding and capability in applying technology in this digital era because most of internet sites use English as the language instruction.

Castillo \& Gamez (2013) as citied in Shelor (2016) suggests parents to play critical roles in supporting children to develop their language learning at home. It can be implemented by providing various learning media as it is commonly perceived that children learning language by doing something interesting through their five senses (Brown, 2007). Additionally, Fatt (2000) argues that visual aids: pictures, flash cards, books, games and printed materials can help children learn language as well as build their creative thinking through what they see. Meanwhile, Brannon, Dauksas, Coleman, Israelson, \& Williams (2013) reveal that literacy home activities such as dialog reading and shared reading have been examined to be beneficial in English language learning. On the other hand, Kayalar \& Kayalar (2017) investigate that auditory learning can be both determinative and significative for effective language learning. While, audio-visual media such as television, video, YouTube, computer and films are claimed to be more attractive for children since they can listen and watch at the same time (Idris et al., 
2018). Accordingly, Shyamlee \& Phil (2012) state that audio-visual can stimulate children building their analytical, creative and productive skills.

There are always some challenges when dealing with children learn second language compared with adults as their cognitive and linguistic are still immature (Xiaoyi, 2017). Children are unlike adults who usually use their abstract and logical ways in processing the knowledge of language because they take less anxiety in learning second language (Gürsoy \& Akin, 2013). The low level of parents' education can be the factor which leads to their less involvement in their children language acquisition since they are not confident enough to use English for communication (Poyraz, 2017). Nevertheles, Castillo \& Gamez (2013) as citied in Shelor (2016) describes how non-native parents may involve in the process of children second language acquisition by giving an analogy that to teach children ride a bike parents do not necessarily have to be able to ride a bike. It is in line with Xuesong (2006) who discovered that parents kept on assisting their children's learning although they didn't master English.

Some previous studies related to the parents' involvement in their children's English language learning have been conducted. The first study was carried out by Xuesong (2006) to investigate parents' involvement in a group of students from urban China. The results indicated that parents played a significant role in their children's English learning. Parents exposed the English language to their children with some strategies such as giving continues encouragement in learning English, providing English learning in TV program and financing children for English course. Another study was undertaken by Xiaoyi (2017) to explore how parents involved in children's learning in an English center in China. The results of the research revealed that in the context of English training center, parents got involved in their children's English learning by asking their children about their learning, accompanying and supervising homework, building communication with teachers, joining school activities and administering for extracurricular courses. Additionally, Poyraz (2017) undertook a research on parents' involvement in their children's home-based English activities and the result showed that their awareness of the importance of the involvement increase as they have higher education level.

In Indonesian context, English has been taught at the elementary school level as a foreign language. As a result, Indonesian students begin to learn English at their young age. In this case, parents play significant role to provide continual encouragement and motivation to their children's English language learning (Daniel et al., 2018). However, the rapid, complex and continuous societal changes in this digital era might impact and alter the possibilities related to the parents' involvement. Based on this background, the current study attempted to explore the triggers and barriers of parents' home-based involvement in their children's English language learning and also to find out the features of their involvement. The qualitative research by implementing semi-structured, in- depth interview with four parents of elementary school students at one of private schools in Yogyakarta city was conducted. In order to meet the objectives, the research questions were formulated:

1. What are the triggers and barriers of the parents' home-based involvement in their children's English language learning?

2. How do parents involve themselves in their children's English language learning activities?

\section{METHOD}

This study aimed at exploring the parents' home-based involvement in their children's English 
language learning. The researchers collected the data by employing qualitative descriptive that enabled the researchers to gain rich data of parents' feeling, thoughts, perspectives, and experiences regarding to the research topic (Seidman 2006; Creswell 2014), and examined the data to provide a description of their home based involvement in their children's English learning.

Purposive sampling was chosen by the researcher to select the sample of participants. The four selected participants were the mothers of elementary school students at one of the private schools in Yogyakarta city which has implemented some technological learning tools. The female parents were chosen since parent's gender can be one of the contributing factors in parental involvement level (Feuerstein \& Feuerstein, 2010; Jafarov, 2015). In this case, mothers might spend more time dealing with their children's home learning activity (Jordan et al., 2002). The background of children age, $6.5-8.5$ years old, became another consideration as it is in accordance with Hornby \& Lafaele (2011); Jafarov (2015) and Poyraz (2017) who reveal that students' age has been an issue affecting the level of parental involvement in which it will decrease in upper grades. In addition, some other parents' background in terms of occupation and educational level were also considered in the selection in order to gain a broad range of perspectives. According to Poyraz (2017), parents' various background might affect the parental involvement. The parent-participants various background is displayed in the following table:

\begin{tabular}{lllll}
\hline Background & Parent 1 (P1) & Parent 2 (P2) & Parent 3 (P3) & Parent 4 (P4) \\
\hline Gender & Female & Female & Female & Female \\
\hline Occupation & Dentist & Lecturer & House wife & Plant Seller \\
\hline $\begin{array}{l}\text { Educational } \\
\text { level }\end{array}$ & $\begin{array}{l}\text { Bachelor of } \\
\text { Dentistry }\end{array}$ & Post Graduate & High school & High school \\
\hline Children's age & 6,5 & 7 & 7.5 & 8,5 \\
\hline Children's grade & $1^{\text {st }}$ grader & $2^{\text {nd }}$ grader & $2^{\text {nd }}$ grader & $3^{\text {rd }}$ grader \\
\hline
\end{tabular}

In order to gain the data the researchers did the interview and recorded it. The semi-structured, in- depth interview was implemented in this study since it is one of the instruments that can be used in to gather the data in a qualitative research (Gopaldas, 2016; Levitt et al., 2017). Based on consideration of the theoretical background of the research topic (Kvale, 2007) to process the analyzing interview, the main concepts of the theoretical background were concisely categorized in order to formulate the interview questions. Accordingly, the researchers developed some questions based on the theoretical categories. In reference to Lin, Ching-Ying \& Chen (2016); Mosty \& Lefever, (2013); Povey et al., (2016); Reddy \& English (2016); Selwyn et al., (2011); Wei, (2011); Wilder, 2014; Willis \& Exley (2018); M. Xiaoyi (2017), the researchers asked the participants about the triggers of their involvement. Additionally, the researcher focused on asking the participants the barriers of their involvement (Goodall, 2017; Jafarov, 2015; Poyraz, 2017; Xuesong, 2006).

Finally, in accordance to Benner et al., (2016) the researcher asked the participants the features of their involvement in their children's English language learning. The interview questions were formulated in the following table. 


\begin{tabular}{|c|c|c|}
\hline No & Categories & Questions \\
\hline 1. & $\begin{array}{l}\text { The triggers of parents' } \\
\text { involvement }\end{array}$ & $\begin{array}{l}\text { 1. What is your perception/belief of English language } \\
\text { learning? Does it trigger your involvement in your } \\
\text { children's English language learning? Please share your } \\
\text { experience. } \\
\text { 2. How do the technological learning tools that are } \\
\text { implemented by the school impact your involvement? } \\
\text { Please share your experience. } \\
\text { 3. Do you have expectations of your children academic } \\
\text { achievement? Do they influence your home-based } \\
\text { involvement? Please share your experience. }\end{array}$ \\
\hline 2. & $\begin{array}{l}\text { The barriers of parents' } \\
\text { involvement }\end{array}$ & $\begin{array}{l}\text { 4. Do you have sufficient time in your parental home- } \\
\text { based involvement? } \\
\text { 5. Do you encounter barriers in your involvement in your } \\
\text { children language learning which related to socio- } \\
\text { economic situation? Please share your experience. } \\
\text { 6. Does your level of English ability become an obstacle } \\
\text { to get involved in your children language learning? } \\
\text { Please share your experience. } \\
\text { 7. Do you find impediments in your involvement related } \\
\text { to the school implementation of technological learning } \\
\text { tools? }\end{array}$ \\
\hline 3. & $\begin{array}{l}\text { The features of parents' } \\
\text { involvement }\end{array}$ & $\begin{array}{l}\text { 8. How do you involve yourself in your children's English } \\
\text { language learning? } \\
\text { 9. Do you provide some learning media for your } \\
\text { children's English language learning? Please share your } \\
\text { experience. }\end{array}$ \\
\hline
\end{tabular}

Table 2

Finally, after collecting data the researcher did transcribing, describing, and deep analyzing the data in order to code them into some inter-related categories. Three main categories which emerged were the triggers of parents' home-based involvement, the barriers of parents' homebased involvement and the features of parental home-based involvement.

\section{RESULTS AND DISCUSSION}

\section{Results}

\section{The Triggers of Parents' Home-Based involvement}

The data reveals that there are some triggers in parents' home-based involvement. Parent 1 believed that learning English was very valuable for her daughter since she thought that her child needed to be equipped with English proficiency in consideration of the status of English as an international language. This belief had been a trigger for her to support her daughter in learning English. Moreover, she perceived that home-based parental involvement was crucial for her daughter more specially when dealing with new English learning platforms. She expected that her involvement could enhance her daughter's academic achievement:

"In my view English has been an international language and it becomes a trigger for everyone to have a capability in English. That's why I always support my daughter to learn English as I know how important English is. I believe if my daughter is proficient in English, it will be very useful for her future. Furthermore, I believe that parents' 
home-based involvement is crucial for my daughter, more specially now she has to deal with some digital learning platforms in learning English at home such as Google Meet, Google classroom, YouTube and some online English exercises. Of course, these new learning platforms really need more parents' involvement because my daughter is still 6 years old. I hope that I can help her to enhance her academic achievement". (Parent 1)

Similarly, Parent 2 perceived English as the international language for going global and it was very important to be learned by her kid for successful communication. Further, based on her view home-based parental involvement was significant for her daughter's learning progress in English and it became more demanding due to the use of technological platforms in learning.

"In my view English is the International language, it is the language for going global. I encourage and support my daughter to love English because English is one of the important elements for successful communication. I have set goals for her specially related to her English learning attainment. I hope that she will be able to understand, to communicate as well as be familiar with it. I value that when I get involved in my kid' home learning, it will be significant and it will be an encouragement for her. Regularly I try to give consistent assist to my daughter' in completing any English tasks, more specially, now there some changes in educational learning system where she has to attend any virtual classes including English which, of course, it requires more parents' involvement. (Parent 2)

Parent 3 viewed that learning English was important for her child to have better future. Also, she perceived that home-based parents' involvement was beneficial for her kid to gain learning progress and academic achievement. She always tried her best to get involved in her kid's English learning specially when her kid dealt with some technological tools utilized by the school:

"I believe English is very important to be learned by my child because it will help him to be able to compensate in the development of this increasingly advanced era. More specially it will be useful for his future careers as they have a "plus value" (English competence) and the opportunity to be successful is wide open. I hope that my child will get the better future than us (his parents). in my opinion, parents' support and engagement in children learning will be meaningful for them because parents must be the ones who understand them most. For me personally, as a full-time house wife, I always have time to get involved in my son's English home learning. Moreover, the school implementation of some digital tools in learning requires me to get involved as the learning activities mostly held at home."(Parent 3)

Meanwhile, Parent 4 stated that it was important to learn English to be able deal with digital technology for gaining knowledge. In her perception, children could get their best attainment in learning if there was a consistent support from their parents since they still depended on their parents. Additionally, she believed that the changes of learning deliverance using digital tools really called for more parents' involvement. However, in her view, not all parents were ready for the changes, including she herself due to some factors:

"I believe that English is important to be learned by son because this modern era has required everyone to be able to communicate in English as well as to gain knowledge using digital technology. I observe that recently my child always learns his school lessons by using any digital platforms such us Zoom, YouTube and any online exercises 
which mostly using English. Of course, this phenomenon has called for parents to get involved more in children home learning. However, I think not all of parents are ready to deal with this change including me myself due to some factors." (Parent 4)

The data above shows that parents have some triggers in their parental home-based involvement in their children's English language learning. The first trigger is parents' belief of the importance of English. They perceive that English, as international language, is important to be learned by their children. Furthermore, they view that their children need to be proficient in English in order to support them in achieving their successful future careers and also to equip them in gaining knowledge and information through digital technology which mostly using English. While, the second trigger is the school implementation of technological learning tools which requires more parents' involvement. The children still depend on their parents to deal with technological tools in learning. Finally, the third trigger is parents' expectation of their children academic achievement. They expect that their involvement will enhance their children best attainment in learning.

\section{The Barriers of Parents' Home-Based Involvement}

The data reveals that parents still encounter with some barriers in their parental home-based involvement. Parent 1 said that her impediment was related to the lack of time availability to accompany her child doing home learning due to her job as a dentist, however, she was able to deal with this problem:

"Unfortunately, due to my job as a dentist I cannot always assist my daughter in her home learning. To deal with this situation I often ask for my mom (her grandma) and her private teacher to help me accompany my daughter in her home learning. Also, I always monitor my daughter's learning through phone call or video call." (parent 1)

While parent 3 stated that her unproficiency in English had been her barrier in her involvement:

"I think my kid mostly still needs me to assist him engaging in his English lesson specially to understand the learning topic, to complete any English tasks and also to have tests preparation. Honestly, I still have obstacle in assisting my kid's English learning since I am not proficient and not fluent in English yet I hope that my kid will have better English competence than me. I try best to assist my kid's learning in spite of my obstacles." (Parent 3)

Parent 4 believed that getting involved in her kid's home learning activities was really needed, however, she had very limited time for assisting her kid's English home learning due to the family socio-economic situation in which she had to make money outside home. The unfamiliarity in using technological tools also had been another impediment that she encountered.

"Personally, I believe that fully getting involved in my kid's English learning is very demanding specially when dealing with any online tasks. I think in his age, my kid still needs my accompaniment in completing her English tasks. However, it becomes dilemma for me since at the same time my husband and me have to earn money by going around selling plants. We have limited time to assist our daughter to do her home learning tasks. As a result, sometime my daughter could not submit her learning 
tasks on time. The unfamiliarity of using technological tools also becomes the other obstacles. It is hard me to be fully involved in my kid's home learning process." (Parent 4)

The data above reveals barriers that parents encounter in their home-based involvement. Those are related to parents' lack of time, parents' unproficiency in English and parents' unfamiliarity with the use of technological tools.

\section{The Features of Parents' Home-Based Involvement}

Parent 1 dedicated her efforts to get involved in her daughter' English learning by monitoring her English learning activities, providing some fun media though videos and also financing the private course.

“Even though I can't always be at home to accompany my daughter's learning but I try to be regularly getting involved in my daughter's English home learning activities, such as monitoring her English tasks completion, rechecking her homework, having discussion with my daughter, preparing her test material and compiling all of her English material files in a folder. We also finance our daughter a private English course to support her acquiring English. Additionally, I provide some fun English learning media to enhance her daughter's English ability through videos. " (Parent 1)

Similarly, parent 2 provided guidance and accompaniment for her kid's English home learning as well as additional English learning media in which her kid would be able to practice English both written and oral English.

"I usually talk to them in English with simple words/sentences, and encourage them to practice periodically so that English becomes a familiar language at home. I support them with English story books, and I usually read aloud when reading it so that they are familiar to listen to English story and English vocabulary as well. I provide both of my children additional English learning media at the English course where they can have more access to learn and practice English both written and oral English. I usually encourage my children to do their homework or tasks by themselves, then I check their works after completing. It is the time when I give them inputs so that they know their competence to improve." (Parent 2)

Even though Parent 3 was not fluent in English but she kept on accompanying her son to accomplish his English school assignments and provided internet access to find some supporting learning media such us YouTube videos, English songs and children's English movies. Sometimes she asked her son to practice some fun English games:

"Though I am not proficient and not fluent in English as I was not good in English when I was at my school but I try to dedicate my best efforts to support my son in learning English. I always accompany him to accomplish English school assignments and help him if he has any difficulties. I provide internet access so that he can search his favorite English songs and movies. Sometimes I ask my son to practice some fun English games that we find from YouTube. I think that my son and me learn English together." (Parent 3) 
Parent 4 provided limited assistance and accompaniment for her daughter's home learning because of her job:

"I have limited time to involve in my daughter's home-learning as I have to work outside. I have consulted this impediment to the teacher then my daughter is allowed to do her home learning in the evening session." (Parent 4)

Based on the data gathered home-based parental involvement can be in the forms of parents constant monitoring, parents' accompaniment and parents' assistances in their children's learning at home activities. Financing an English private course and providing additional English learning media such as videos, online games, English songs and English story books become the other features of parents' support in their children's English learning.

\section{Discussion}

The result shows there are three main triggers in parents home-based involvement: the first trigger is parents' belief in the language learning. Parents perceive English, as international language, is important to be learned by their children in order to support them in achieving their successful future careers and gaining knowledge and information through digital technology. This finding supports (Dewi et al., 2017 ; Ivankova, Creswell, \& Stick, 2006; Mosty \& Lefever, 2013; Reddy \& English, 2016; Xiaoyi, 2017) who assert that children's language learning might be mainly indicated by both belief and attitude possessed by parents in the language. The second trigger is the school implementation of technological learning tools which requires more parents' involvement since the children still depend on their parents to deal with these tools in learning.

The finding is in line with Selwyn et al., (2011) and Willis \& Exley (2018) who claim that school's learning platforms technologies are considered to increase parental involvement as parents will be enabled to gain information and resources related to their children's education as well as to support and review their children's learning. While the third trigger is parents' expectation of their children academic achievement. They expect that their involvement will enhance their children best attainment in learning. This finding is in correlation with Hosseinpour (2015); Povey et al., (2016); Rahman, (2015) who argue that parental involvement provides motivation and encouragement during the learning processes. The data above reveals barriers that parents encounter in their home-based involvement. The first barrier is the lack of parental time availability. This finding corresponds with Jafarov (2015) who states that parents lack of time can be one of problems in parental involvement. The insufficient time in parental involvement might be related to the family socio-economic situation as parent 3 experiences with. This result is in relation with Poyraz (2017); Jafarov (2015); Larocque et al., (2011) who assert that socio-economic situation can affect parents' involvement in their children language learning. The second problem is parents' unproficiency in English. This finding supports (Poyraz, 2017) who claims that the parents' incompetence in English due to the low level of education can be the factor which leads to their less involvement in their children language learning. While the fourth impediment is parents' unfamiliarity with the use of technological tools. It is in accordance with Goodall, 2017 and Povey et al., 2016 who discover that the inability of parents to access the technological tools can be one of the obstacles and some parents regard learning platform merely just as an additional burden for them.

Based on the data gathered home-based parental involvement are in the forms of parents constant monitoring, parents' accompaniment, parents' assistances, parents-child discussion in 
their children's learning at home activities and financing an English private course. This finding is in correlation with Benner et al., (2016); Castillo \& Gamez (2013) who state that parents can play critical roles in supporting children to develop their language learning at home. Providing additional English learning media such as videos, online games English songs and English story books become the other features of parents' support in their children's English learning. This result is in correlation with (Idris et al., 2018) who claim that audio-visual media is more attractive for children since they can listen and watch at the same time. Additionally, Brannon et al., (2013) describe that literacy home activity has been examined as a beneficial English language learning.

\section{CONCLUSION}

The results display the triggers, barriers and features of parents' home-based involvement. There are three main triggers in the parents' home-based involvement in children's English language learning. The first trigger is parents' belief of the importance of English. While, the second trigger is the school implementation of technological learning tools which requires more parents' involvement. Finally, the third trigger is parents' expectation of their children academic achievement. The finding also reveals the barriers that parents encounter in their home-based involvement. Those are related to parents' lack of time, parents' unproficiency in English and parents' unfamiliarity with the use of technological tools. Finally, it is revealed that the features of home-based parental involvement emerged in the forms of parents' constant monitoring, parents' accompaniment and parents' assistances in their children's learning at home activities. Financing an English private course and providing additional English learning media such as videos, online games, English songs and English story books become the other features of parents' support in their children's English learning. Since this study was conducted by exploring parents' involvement whose children study at school which located in a city. We recommend further research to investigate the involvement of parents whose children study in rural areas.

\section{ACKNOWLEDGMENTS}

We would like to express our gratitude to all the participants who have been willing to get involved in this study. We also gratefully appreciate all friends and relatives who have contributed to the completion of this study.

\section{REFERENCES}

Benner, A. D., Boyle, A. E., \& Sadler, S. (2016). Parental Involvement and Adolescents' Educational Success: The Roles of Prior Achievement and Socioeconomic Status. Journal of Youth and Adolescence, 45(6), 1053-1064. https://doi.org/10.1007/s10964-016-0431-4

Brannon, D., Dauksas, L., Coleman, N., Israelson, L., \& Williams, T. (2013). Measuring the Effect That the Partners' Dialogic Reading Program Has on Preschool Children's Expressive Language. Creative Education, 04(09), 14-17. https://doi.org/10.4236/ce.2013.49b004

Butler, Y. G. (2014). Parental factors and early English education as a foreign language: A case study in Mainland China. Research Papers in Education, 29(4), 410-437. https://doi.org/10.1080/02671522.2013.776625

Castillo, R., \& Gamez, L. C. C. (2013). Assisting your Child' s Learning in L2 is like Teaching them to Ride a Bike : A Study on Parental. Gist Education and Learning Research Journal, 7(7), 54-73. 
Daniel, C., Halimi, F., \& AlShammari, I. (2018). The Impact of Motivation and Parental Encouragement on English Language Learning: An Arab Students' Perspective. Reading Matrix: An International Online Journal, 18(1), 176-194.

Dewi, K. C., Asib, A., \& Drajati, N. A. (n.d.). Cultural contents in an English language teaching (ELT) textbook: A case of Indonesia. 1-10.

Fatt, J. (2000). Understanding the learning styles of students. International Journal of Sociology and Social Policy, 20(11), 31-45.

Feuerstein, A., \& Feuerstein, A. B. E. (2010). School Characteristics and Parent Involvement : Influences on Participation in Children's Schools. November 2014, 37-41. https://doi.org/10.1080/00220670009598740

Fiszbein, A., \& Stanton, S. (2018). The future of Education in Latin America and the Caribbean. June.

Goodall, J. S. (2017). Technology and school - home communication. International Journal of Pedagogies and Learning, 0552(March), 1-14. https://doi.org/10.1080/22040552.2016.1227252

Gopaldas, A. (2016). A front-to-back guide to writing a qualitative research article. Qualitative Market Research, 19(1), 115-121. https://doi.org/10.1108/QMR-08-2015-0074

Gürsoy, E., \& Akin, F. (2013). Is younger really better? anxiety about learning a foreign language in Turkish children. Social Behavior and Personality, 41(5), 827-842. https://doi.org/10.2224/sbp.2013.41.5.827

Hornby, G., \& Lafaele, R. (2011). Barriers to parental involvement in education: an explanatory model. 63(1), 37-52. https://doi.org/10.1080/00131911.2010.488049

Hosseinpour, V. (2015). The Relationship between Parents 'Involvement, Attitude , Educational Background and Level of Income and Their Children 's English Achievement Test Scores. 6(6), 1370-1378.

Idris, A. T., Shamsuddin, I. M., Arome, A. T., \& Aminu, I. (2018). Use of Audio-Visual Materials in Teaching and Learning of Classification of Living Things Among Secondary School Students in Sabon Gari LGA of Kaduna Use of Audio-Visual Materials in Teaching and Learning of Classification of Living Things Among Secondary School Students in Sabon Gari LGA of Kaduna State. August. https://doi.org/10.11648/j.plant.20180602.12

Ivankova, N. V., Creswell, J. W., \& Stick, S. L. (2006). Using Mixed-Methods Sequential Explanatory Design: From Theory to Practice. Field Methods, 18(1), 3-20. https://doi.org/10.1177/1525822X05282260

Jafarov, J. (2015). Factors Affecting Parental Involvement in Education: The Analysis of Literature. Khazar Journal of Humanities and Social Sciences, 18(4), 35-44. https://doi.org/10.5782/2223-2621.2015.18.4.35

Jeynes, W. H. (2007). The Relationship Between Parental Involvement and Urban Secondary School Student Academic Achievement. 82-110.

Jordan, C., Orozco, E., \& Averett, A. (2002). Emerging issues in school, family and community connections.

Kayalar, F., \& Kayalar, F. (2017). The effects of Auditory Learning Strategy on Learning Skills of Language Learners ( Students' Views) The effects of Auditory Learning Strategy on Learning Skills of Language Learners ( Students, Views ). October. https://doi.org/10.9790/0837-2210070410

Larocque, M., Kleiman, I., Darling, S. M., Larocque, M., Kleiman, I. R. A., \& Darling, S. M. (2011). Parental Involvement: The Missing Link in School Achievement Parental Involvement: The Missing Link in School Achievement. 4387. https://doi.org/10.1080/10459880903472876

Levitt, H. M., Motulsky, S. L., Wertz, F. J., Morrow, S. L., \& Ponterotto, J. G. (2017). 
Recommendations for designing and reviewing qualitative research in psychology. Qualitative Psychology, 4(1), 2-22.

Lin, Ching-Ying \& Chen, H.-C. (2016). Parental Perceptions of Early Childhood English Education. 4(11), 62-70.

Mosty, N. L., \& Lefever, S. (2013). Parents ' perspectives towards home language and bilingual development of preschool children. 1-18.

Povey, J., Kate, A., Willis, L., Haynes, M., Western, M., Bennett, S., Antrobus, E., \& Pedde, C. (2016). Engaging parents in schools and building parent-school partnerships : The role of school and parent organisation leadership. International Journal of Educational Research, 79, 128-141. https://doi.org/10.1016/j.ijer.2016.07.005

Poyraz. (2017). The effects of parental involvement in English language learning of secondary school students Erol Poyraz 1 Bahçeşehir University, İstanbul -Turkey.

Rahman, M. A. (2015). A Study on How Home Environment Influences Adolescent L2 Learners of English in Bangladesh.

Reddy, M. S., \& English, L. (2016). Importance of English Language in today' $s$ World Introduction : 3(4), 179-184.

Selwyn, N., Banaji, S., \& Clark, W. (2011). Providing a platform for parents? Exploring the nature of parental engagement with school Learning Platforms. 314-323. https://doi.org/10.1111/j.1365-2729.2011.00428.x

Shelor. (2016). No Title. May.

Shyamlee, S., \& Phil, M. (2012). Use of technology in English language teaching and learning: An analysis. A Paper Presented at the 2012 International Conference on Language, Medias and Culture IPEDR Vol.33 (2012) @(2012) IACSIT Press, Singapore, 33(2012), $150-156$.

Ule, M., Živoder, A., \& Bois-reymond, M. (n.d.). International Journal of Qualitative Studies in Education 'Simply the best for my children ': patterns of parental involvement in education. February 2015, 37-41. https://doi.org/10.1080/09518398.2014.987852

Wei, R. (2011). Journal of Multilingual and Parental support for Chinese - English bilingual education : a survey of parents of primary and secondary students in Shanghai. October 2014, 37-41. https://doi.org/10.1080/01434632.2011.592588

Wilder, S. (2014). Effects of parental involvement on academic achievement : a meta-synthesis. October, 37-41. https://doi.org/10.1080/00131911.2013.780009

Willis, L. D., \& Exley, B. (2018). Using an online social media space to engage parents in student learning in the early-years: Enablers and impediments. Digital Education Review, 33, 87-104. https://doi.org/10.1344/der.2018.33.87-104

Xiaoyi, M. (2017). Ma Xiaoyi Parental involvement in children 's foreign language learning: Improving 6-12 year-old pupils 'English through parent-school interaction A case study in China University of Eastern Finland Philosophical Faculty School of Applied Educational S. March.

Xuesong, G. (2006). Strategies used by Chinese parents to support English language learning: Voices of "Elite" University students. RELC Journal, 37(3), 285-298. https://doi.org/10.1177/0033688206071302 